\title{
Discovery of Antimalarial Azetidine-2-carbonitriles That Inhibit P. falciparum Dihydroorotate Dehydrogenase
}

\section{Citation}

Maetani, Micah, Nobutaka Kato, Valquiria A. P. Jabor, Felipe A. Calil, Maria Cristina Nonato, Christina A. Scherer, and Stuart L. Schreiber. 2017. "Discovery of Antimalarial Azetidine-2-carbonitriles That Inhibit P. falciparum Dihydroorotate Dehydrogenase." ACS Medicinal Chemistry Letters 8 (4): 438-442. doi:10.1021/acsmedchemlett.7b00030. http:// dx.doi.org/10.1021/acsmedchemlett.7b00030.

\section{Published Version}

doi:10.1021/acsmedchemlett.7b00030

\section{Permanent link}

http://nrs.harvard.edu/urn-3:HUL.InstRepos:32630685

\section{Terms of Use}

This article was downloaded from Harvard University's DASH repository, and is made available under the terms and conditions applicable to Other Posted Material, as set forth at http:// nrs.harvard.edu/urn-3:HUL.InstRepos:dash.current.terms-of-use\#LAA

\section{Share Your Story}

The Harvard community has made this article openly available.

Please share how this access benefits you. Submit a story.

Accessibility 


\title{
Discovery of Antimalarial Azetidine-2-carbonitriles That Inhibit $P$. falciparum Dihydroorotate Dehydrogenase
}

\author{
Micah Maetani, ${ }^{\dagger \neq}$ Nobutaka Kato, ${ }^{\ddagger}$ Valquiria A. P. Jabor, ${ }^{\S}$ Felipe A. Calil, ${ }^{\S}$ Maria Cristina Nonato, ${ }^{\S}$ \\ Christina A. Scherer, ${ }^{\ddagger}$ and Stuart L. Schreiber $*,+, \| \infty$
}

${ }^{\dagger}$ Department of Chemistry and Chemical Biology, Harvard University, Cambridge, Massachusetts 02138, United States

${ }^{\ddagger}$ Broad Institute, Cambridge, Massachusetts 02142, United States

${ }^{\S}$ School of Pharmaceutical Sciences of Ribeirão Preto, University of São Paulo, Ribeirão Preto, São Paulo 14040-903, Brazil

"Howard Hughes Medical Institute, Cambridge, Massachusetts 02138, United States

\section{Supporting Information}

ABSTRACT: Dihydroorotate dehydrogenase (DHODH) is an enzyme necessary for pyrimidine biosynthesis in protozoan parasites of the genus Plasmodium, the causative agents of malaria. We recently reported the identification of novel compounds derived from diversityoriented synthesis with activity in multiple stages of the malaria parasite life cycle. Here, we report the optimization of a potent series of antimalarial inhibitors consisting of azetidine-2-carbonitriles, which we had previously shown to target $P$. falciparum $\mathrm{DHODH}$ in a biochemical assay. Optimized compound BRD9185 (27) has in vitro activity against multidrug-resistant blood-stage parasites $\left(\mathrm{EC}_{50}=0.016 \mu \mathrm{M}\right)$ and is curative after just three doses in a $P$. berghei mouse model. BRD9185 has a long half-life $(15 \mathrm{~h})$ and low clearance in mice and represents a new structural class of DHODH inhibitors with potential as antimalarial drugs.

KEYWORDS: BRD7539, BRD9185, DHODH, malaria, diversity-oriented synthesis, Plasmodium falciparum
$\mathrm{M}$ alaria is a global health concern with nearly 200 million cases annually, many of which occur in sub-Saharan Africa. The disease is caused by parasitic protozoans of the genus Plasmodium and transmitted by female Anopheles mosquitos. ${ }^{1}$ Malaria is treatable using chemotherapy, but reduced efficacy of first-line treatments artemisinin and its derivatives at the Cambodia-Thailand border underscores the need for new, safe, and effective antimalarial therapies. ${ }^{2-5}$ Moreover, while most current antimalarial drugs target asexual blood-stage parasites, next-generation antimalarials should ideally also target the liver- and/or sexual blood-stage parasites to impede parasite replication and transmission from host-tovector, respectively. ${ }^{6} \mathrm{New}$ antimalarial candidates have entered clinical trials in this regard, including one that targets dihydroorotate dehydrogenase (DHODH).

DHODH catalyzes the flavin mononucleotide (FMN)dependent oxidation of L-dihydroorotate to orotate as the fourth step in de novo pyrimidine biosynthesis. While most organisms use both de novo and salvage pathways to generate pyrimidines, Plasmodium parasites lack the necessary genes for the latter, making de novo pyrimidine synthesis an essen-

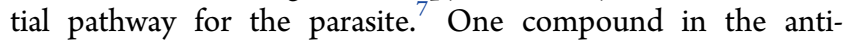
malarial pipeline, DSM265, has progressed to phase-II clinical trials and has activity against both asexual blood-stage and liverstage parasites. ${ }^{8}$ DSM265 and secondary candidate DSM421 (Chart 1) comprise a class of selective and potent antimalarial DHODH inhibitors. ${ }^{9-15}$ These triazolopyrimidines remain the
Chart 1. Structures of PfDHODH Inhibitors in Clinical or Preclinical Development
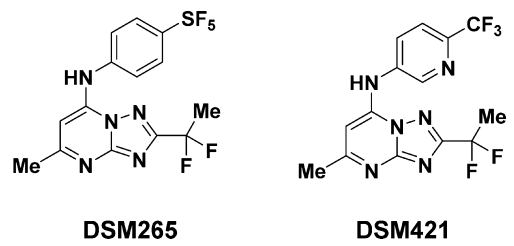

most well-studied and clinically relevant antimalarial DHODH inhibitors to date, but 5-benzimidazolyl-thiophene-2-carboxamides $^{16}$ and 7 -arylaminopyrazolo[1,5- $\alpha$ ]pyrimidines have also been reported. ${ }^{17}$

We recently identified numerous compounds with multistage activity by growth-inhibition phenotypic screening of 100,000 compounds prepared in advance using diversity-oriented synthesis (DOS). ${ }^{18}$ The DOS collection was synthesized using modern asymmetric organic chemistry to impart threedimensional topographical features using the build-couplepair strategy. ${ }^{19}$ The success of this strategy in revealing novel therapeutic targets is illustrated by the discovery of small-molecule antimalarial inhibitors of phenylalanyl-tRNA

Received: January 20, 2017

Accepted: February 27, 2017

Published: February 27, 2017 
synthetase, ${ }^{18} \mathrm{PI} 4 \mathrm{~K},{ }^{18}$ and cytochrome bc1 $\mathrm{Q}^{20,21}$ as well as others with as-yet unidentified targets. ${ }^{22}$ While our initial efforts focused on small-molecule inhibitors of phenylalanyl-tRNA synthetase, we became intrigued in BRD7539, which we had previously shown to target PfDHODH $\left(\mathrm{IC}_{50}=0.033 \mu \mathrm{M}\right)$ selectively over human $(H s)$ DHODH $\left(\mathrm{IC}_{50}>50 \mu \mathrm{M}\right)$. BRD7539 was reported to have potent activity against both multidrug-resistant asexual blood-stage (P. falciparum, Dd2 strain, $\left.\mathrm{EC}_{50}=0.010 \mu \mathrm{M}\right)$ and liver-stage $\left(P\right.$. berghei, $\mathrm{EC}_{50}=$ $0.015 \mu \mathrm{M})$ parasites but no activity against sexual blood-stage (P. falciparum, stages IV-V, $\mathrm{EC}_{50}>20 \mu \mathrm{M}$ ) parasites. BRD7539 is an azetidine carbonitrile with three contiguous stereocenters $(2 S, 3 S, 4 S)$, and stereochemistry-based structureactivity relationships (SSARs) showed that only two of eight possible stereoisomers are active. ${ }^{18}$ The clinical relevance of PfDHODH inhibitors and the selectivity and potency of BRD7539 arising directly from a high-throughput screen encouraged us to pursue this series further. Here, we report our efforts to optimize this compound and to evaluate this series in vivo.

To confirm the biological activity of BRD7539 and to explore structure-activity relationships (SARs) of the scaffold, we resynthesized core structure $\mathbf{1}$ (Scheme 1) as reported. ${ }^{23}$

Scheme 1. Elaboration of the Azetidine-2-carbonitrile Scaffold $^{a}$

$\mathrm{Br}$
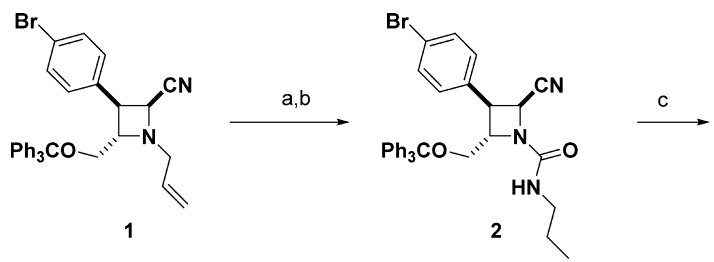

$\mathrm{Br}$
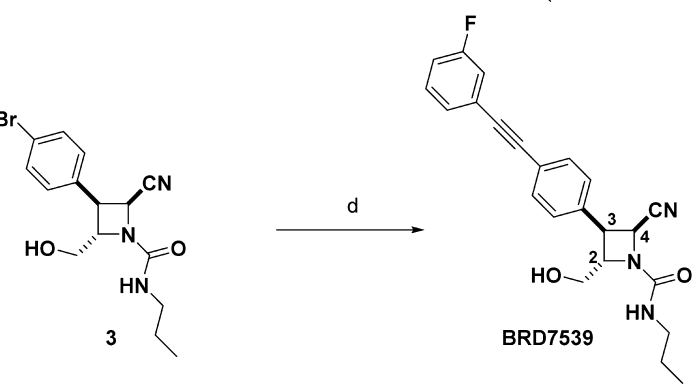

${ }^{a}$ Reagents and conditions: (a) $\mathrm{Pd}\left(\mathrm{PPh}_{3}\right)_{4}, 1,3$-dimethylbarbituric acid, 2:1 EtOH/DCM, $40{ }^{\circ} \mathrm{C}, 16 \mathrm{~h}, 92 \%$; (b) propylisocyanate, DIPEA, DCM, $23{ }^{\circ} \mathrm{C}, 1 \mathrm{~h}, 96 \%$; (c) trifluoroacetic acid, $\mathrm{Et}_{3} \mathrm{SiH}, \mathrm{DCM}, 23{ }^{\circ} \mathrm{C}$, 1 h, 87\%; (d) 1-ethynyl-3-fluorobenzene, XPhos Pd-G3, Et ${ }_{3} \mathrm{~N}, \mathrm{MeCN}$, $70{ }^{\circ} \mathrm{C}, 6 \mathrm{~h}, 91 \%$.

Deallylation of the protected azetidine core and sequential capping of the nitrogen with propyl isocyanate gave urea 2 . Trityl deprotection followed by a Heck alkynylation or Suzuki reaction diversified the para-Br position and served as a route to most analogues. Biological activity of BRD7539 was confirmed in 20-point dose $(n \geq 2$ independent experiments in triplicate) against a multidrug-resistant strain ( $P$. falciparum, Dd2 strain) using a phenotypic blood-stage growth inhibition assay that models a human blood-stage infection. Additionally, in vitro stability against mice and human microsomes for $1 \mathrm{~h}$ was used as a guide to identify analogues with potential in vivo stability.

Our initial SAR focused primarily on the acetylene $\left(R_{1}\right)$ region of BRD7539 as this was the most facile point of

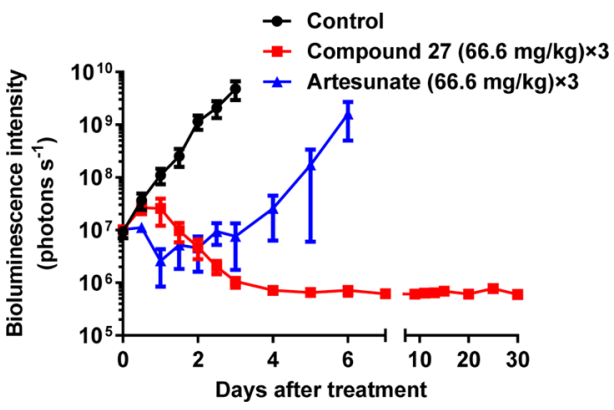

Figure 1. In vivo efficacy studies of BRD9185 (27) using P. berghei mouse model. CD-1 mice were infected with $P$. berghei (ANKA GFP-luc) at $-24 \mathrm{~h}($ Day -1$)$ and dosed orally at 0,24 , and $48 \mathrm{~h}$ with compound 27, artesunate, or vehicle solution. Infections were monitored using the in vivo imaging system (IVIS), and bioluminescence intensity was quantified from each mouse and plotted against time. Animals with parasitemia exceeding $25 \%$ were humanely euthanized. No recrudescence was observed after $3 \times 66.6 \mathrm{mg} / \mathrm{kg}$ doses of $27(n=4)$. By contrast, recrudescence is observed quickly after treatment with $3 \times 66.6 \mathrm{mg} / \mathrm{kg}$ doses of artesunate $(n=2)$.

diversification to explore and a possible toxicity concern (Table 1). ${ }^{24}$ Activity was assessed using the phenotypic bloodstage growth inhibition assay. The activity of BRD7539 was reconfirmed in dose, and in vitro activity was maintained with a wide variety of hydrophobic acetylenes $(4-6,9,10)$. Heteroaromatic 2- and 3-pyridyl analogues (7-8) showed significant loss in activity compared to aromatic analogues. Interestingly, cis-alkene (11) and alkane (12) derivatives of BRD7539 showed only a slight loss in activity, suggesting that the acetylene was not necessary. Indeed, unsubstituted biaryl 13 is essentially equipotent to BRD7539 while removing the distal ring (17, Scheme S1) abolished activity, indicating the need for a large hydrophobic region in the scaffold. Having removed the acetylenic toxicity concern, we decided to use this region to modulate mouse and human microsomal stability while maintaining activity. Improved stability should correlate with favorable pharmacokinetic (PK) properties. Analogues bearing a 4-pyridyl (22) and 4-methanesulfonyl (23) distal aryl were synthesized in an effort to improve solubility but were inactive in vitro. $\mathrm{CF}_{3}$-substitution (24-26) was found to impart greater in vitro microsomal stability than methoxy substituents (28-30). Ultimately, we found that the addition of two $-\mathrm{CF}_{3}$ groups on the distal phenyl ring (BRD9185, 27) to be comparable in activity and microsomal stability to BRD7539.

We briefly sought to evaluate the role of the primary alcohol $\left(\mathrm{R}_{2}\right)$ and secondary nitrile $\left(\mathrm{R}_{3}\right)$ on activity (Table 2$)$. Analogues were synthesized from BRD7539 in 1-3 steps or from commercially available starting materials (Schemes S2-S7). Modifying the nitrile to a methyl ester (32) or alcohol (33) abolished activity. This is unsurprising given our previous result that the $2 S, 3 S, 4 R$ diastereomer, which only differs from BRD7539 at the nitrile-bearing stereocenter, is inactive, hinting at the importance of this functional group. This also illustrates the subtle but significant role stereochemistry can have on small molecule-protein interactions and highlights the strength of diversity-oriented synthesis in identifying these key interactions. Any modification of the primary alcohol, including methylation (34) or conversion to a primary amine (36), resulted in large loss in activity.

To confirm that our lead compound 27 inhibits PfDHODH despite removal of the acetylene motif, we performed biochemical assays against both recombinant $P$. falciparum 
Table 1. Activity of BRD7539 Analogues at $\mathrm{R}_{1}$ Position against Dd2 Parasites ${ }^{a}$

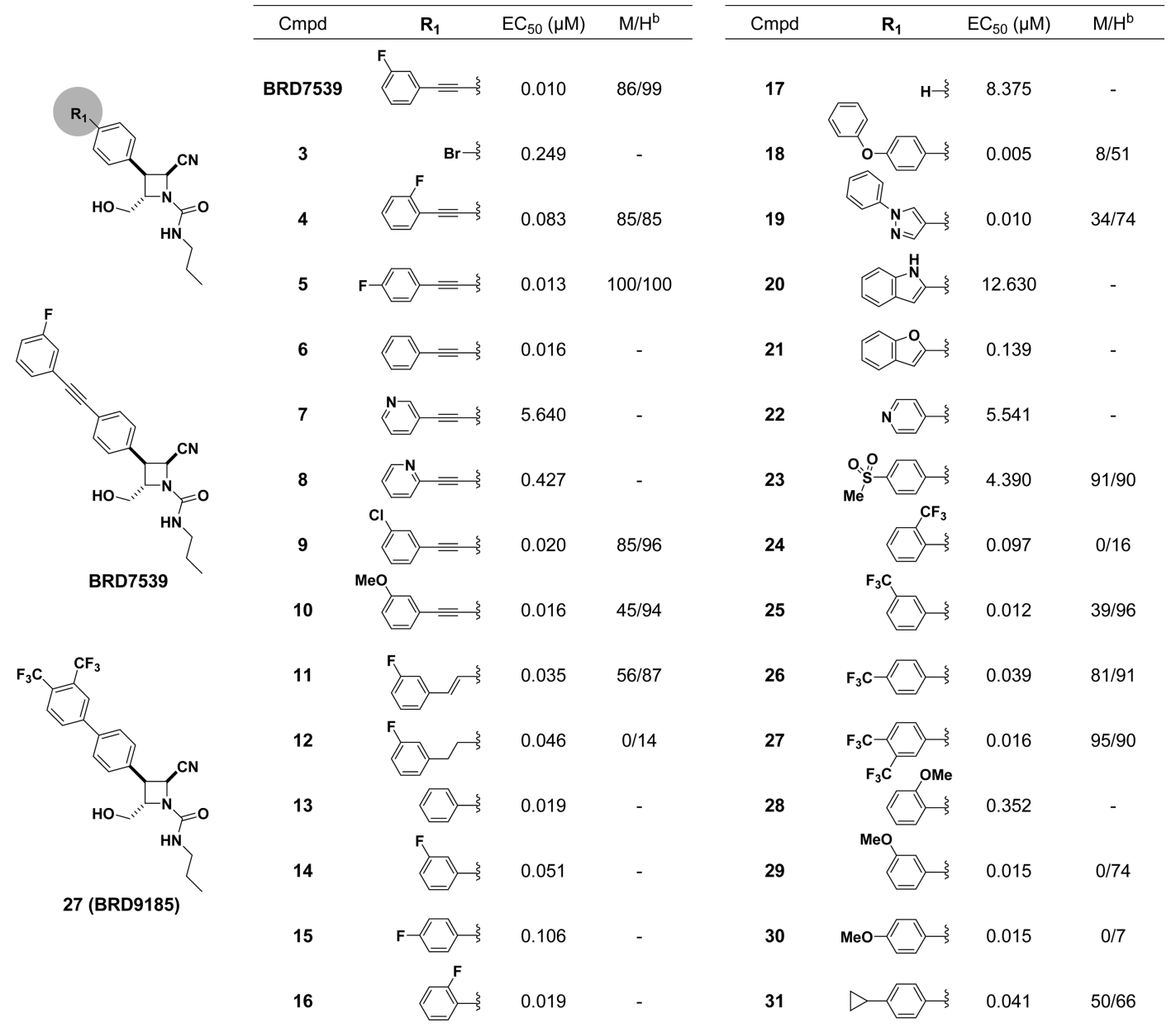

${ }^{a} \mathrm{EC}_{50}$ values are the mean of at least two independent experiments. ${ }^{b}$ Mouse $(\mathrm{M})$ and human $(\mathrm{H})$ microsomal stability (\% remaining after $\left.1 \mathrm{~h}\right)$. Data were obtained from a single experiment performed in duplicate and calculated from a six-point curve over $1 \mathrm{~h}$.

Table 2. Activity of BRD7539 Analogues at $R_{2}$ and $R_{3}$ Positions against Dd2 Parasites ${ }^{a}$

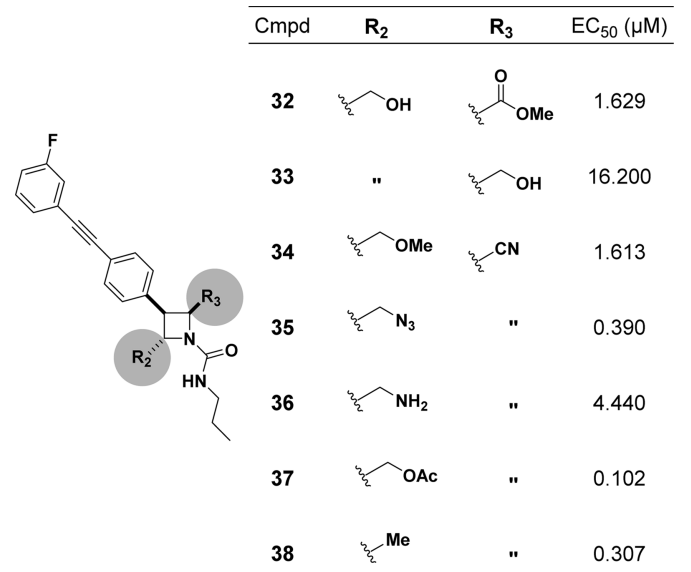

${ }^{a} \mathrm{EC}_{50}$ values are the mean of at least two independent experiments.

and human DHODH enzyme (Table 3, Figure S1). Similar to hit compound BRD7539, 27 is a potent inhibitor of PfDHODH $\left(\mathrm{IC}_{50}=0.012 \mu \mathrm{M}\right)$ but not $\mathrm{HsDHODH}\left(\mathrm{IC}_{50}>\right.$ $50 \mu \mathrm{M})$, suggesting that this class of DHODH inhibitors provides selectivity between orthologues. $\mathrm{The}^{\mathrm{I}} \mathrm{IC}_{50}$ of selected analogues against PfDHODH was also shown to track well with Dd2 $\mathrm{EC}_{50}$ (Table S1). To assess the suitability of BRD9185 further for in vivo use, we measured plasma protein binding and obtained mouse PK data. Lead compound 27 is highly protein bound in both mouse and human plasma (>99\%) and is a highly bioavailable (94\%), long half-life (15 h) compound in mice (PO $5 \mathrm{mg} / \mathrm{kg}$; IV $1 \mathrm{mg} / \mathrm{kg}$ ) with low clearance $(0.40 \mathrm{~mL} / \mathrm{min} / \mathrm{kg})$. Notably, the DNAUC D-inf $_{\text {of }} 27$ is $>54.3 \mu \mathrm{M}$, higher than the $\mathrm{EC}_{50}$ in vitro.

Based on the promising PK properties, we were interested in evaluating the efficacy of 27 in vivo (Figure 1). We used a blood-stage model with the rodent malaria parasite $P$. berghei that expresses luciferase and treated infected CD-1 mice for 3 days with $66.6 \mathrm{mg} / \mathrm{kg}$ of 27 or vehicle (70\% PEG300, 30\% solution of $5 \%$ dextrose in $\mathrm{H}_{2} \mathrm{O}$ ). Bioluminescence intensity was used to measure parasite growth, and artesunate was used as a positive control. No parasites were detected after 30 days in mice treated with 27 , suggesting that the analogue achieved a sterile cure for $P$. berghei. These results are particularly interesting in light of the properties of DSM265 and the triazolopyrimidine series, which are not effective in the $P$. berghei $(P b)$ model due to poor binding to the $P b \mathrm{DHODH}$ enzyme. ${ }^{9,14}$ This raises the possibility that 27 has a different mechanism of action from DSM265 on PfDHODH. However, 27 binds competitively with decylubiquinone (Figure S2), the same proposed binding site as DSM265. ${ }^{8} \mathrm{X}$-ray crystallography studies are underway to gain insights into binding features of these compounds. 
Table 3. Key Properties of Lead Compound 27

\begin{tabular}{|c|c|}
\hline \multicolumn{2}{|c|}{ in vitro enzyme inhibition, $\mathrm{IC}_{50}{ }^{a}$} \\
\hline PfDHODH $(\mu \mathrm{M})$ & 0.012 \\
\hline$H_{s} \mathrm{DHODH}(\mu \mathrm{M})$ & $>50$ \\
\hline \multicolumn{2}{|c|}{ plasma protein binding ${ }^{b}$} \\
\hline mouse (\%) & 99.3 \\
\hline human (\%) & $>99.0$ \\
\hline \multicolumn{2}{|c|}{ mouse $\mathrm{PK}^{c}$} \\
\hline$t_{1 / 2}(\mathrm{~h})$ & 15.2 \\
\hline$C_{0}(\mu \mathrm{M})$ & 4.9 \\
\hline$C_{\max }(\mu \mathrm{M})$ & 16.9 \\
\hline DNAUC $_{0 \text {-inf }}(\mu \mathrm{M} \cdot \mathrm{h})$ & $>54.3$ \\
\hline$V_{\mathrm{ss}}(\mathrm{L} / \mathrm{kg})$ & 0.37 \\
\hline $\mathrm{CL}(\mathrm{mL} / \mathrm{min} / \mathrm{kg})$ & 0.40 \\
\hline$F(\%)$ & 94 \\
\hline
\end{tabular}

${ }^{a}$ Mean of a single experiment in triplicate. ${ }^{b}$ Single experiment, calculated from a six-point curve over $1 \mathrm{~h} .{ }^{c} t_{1 / 2}$, terminal half-life; $C_{0}$, initial serum concentration at $t=0 ; C_{\max }$ peak serum concentration; $\mathrm{DNAUC}_{0 \text {-inf }}$ dose-normalized area under the plasma concentration vs time curve following $\mathrm{PO}$ dosing; $V_{\mathrm{ss}}$, volume of distribution at steady state; CL, plasma clearance; $F \%$, bioavailability. IV dosing in $5 \%$ DMSO/10\% cremophor $/ 85 \% \mathrm{H}_{2} \mathrm{O}$ at $0.25 \mathrm{mg} / \mathrm{mL}(1 \mathrm{mg} / \mathrm{kg})$. PO dosing in 70\% PEG300/30\% (5\% dextrose in $\mathrm{H}_{2} \mathrm{O}$ ) at $0.50 \mathrm{mg} / \mathrm{mL}$ $(5 \mathrm{mg} / \mathrm{kg}) \cdot n=3$ mice in both IV and PO groups.

These data collectively show that azetidine-2-carbonitriles comprise a promising, potent, and selective new class of inhibitors of PfDHODH. In contrast to other antimalarial DHODH inhibitors to date, compound 27 exhibits a sterile cure in an in vivo $P$. berghei model after just three doses. Additional efforts assessing the inhibition of azetidine-2-carbonitriles against DHODH from other Plasmodium species and evaluating efficacy of this series in the humanized NSG mouse $P$. falciparum model are underway.

\section{ASSOCIATED CONTENT}

\section{S Supporting Information}

The Supporting Information is available free of charge on the ACS Publications website at DOI: 10.1021/acsmedchemlett.7b00030.

Supplementary figures, experimental details, compound characterization, and abbreviations (PDF)

\section{AUTHOR INFORMATION}

\section{Corresponding Author}

*E-mail: stuart_schreiber@harvard.edu.

\section{ORCID 1}

Felipe A. Calil: 0000-0001-7503-4078

Christina A. Scherer: 0000-0002-1659-2827

Stuart L. Schreiber: 0000-0003-1922-7558

\section{Funding}

This work was supported in part by the Bill \& Melinda Gates Foundation (grant OPP1032518 awarded to S.L.S.). S.L.S. is an Investigator at the Howard Hughes Medical Institute. M.M. was supported by a fellowship from the National Science Foundation (DGE1144152) and from Harvard University's Graduate Prize Fellowship. Biochemical and mechanistic studies for DHODH were supported by Fundação de Amparo à Pesquisa do Estado de São Paulo (FAPESP), grant number 2012/25075-0 (to M.C.N.).

Notes

The authors declare no competing financial interest.

\section{ACKNOWLEDGMENTS}

We thank Leslie N. Aldrich, Jennifer A. Beaudoin, Christopher J. Gerry, and Jingqiang Wei (Broad Institute) for advice regarding compound synthesis; Eamon Comer and Marshall Morningstar (Broad Institute) for helpful discussions; and Broad Institute Compound Management and analytical teams for assistance with compound access and characterization.

\section{REFERENCES}

(1) WHO. World Malaria Report 2015. http://who.int/malaria/ publications/world-malaria-report-2015/report/en/.

(2) Dondorp, A. M.; Nosten, F.; Yi, P.; Das, D.; Phyo, A. P.; Tarning, J.; Lwin, K. M.; Ariey, F.; Hanpithakpong, W.; Lee, S. J.; Ringwald, P.; Silamut, K.; Imwong, M.; Chotivanich, K.; Lim, P.; Herdman, T.; An, S. S.; Yeung, S.; Singhasivanon, P.; Day, N. P. J.; Lindegardh, N.; Socheat, D.; White, N. J. Artemisinin resistance in Plasmodium falciparum malaria. N. Engl. J. Med. 2009, 361, 455-467.

(3) O’Brien, C.; Henrich, P. P.; Passi, N.; Fidock, D. A. Recent clinical and molecular insights into emerging artemisinin resistance in Plasmodium falciparum. Curr. Opin. Infect. Dis. 2011, 24, 570-577.

(4) Flannery, E. L.; Chatterjee, A. K.; Winzeler, E. A. Antimalarial drug discovery: approaches and progress towards new medicines. Nat. Rev. Microbiol. 2013, 11, 849-862.

(5) Miotto, O.; Almagro-Garcia, J.; Manske, M.; MacInnis, B.; Campino, S.; Rockett, K. A.; Amaratunga, C.; Lim, P.; Suon, S.; Sreng, S.; Anderson, J. M.; Duong, S.; Nguon, C.; Chuor, C. M.; Saunders, D.; Se, Y.; Lon, C.; Fukuda, M. M.; Amenga-Etego, L.; Hodgson, A. V.; Asoala, V.; Imwong, M.; Takala-Harrison, S.; Nosten, F.; Su, X.-Z.; Ringwald, P.; Ariey, F.; Dolecek, C.; Hien, T. T.; Boni, M. F.; Thai, C. Q.; Amambua-Ngwa, A.; Conway, D. J.; Djimde, A. A.; Doumbo, O. K.; Zongo, I.; Ouedraogo, J. B.; Alcock, D.; Drury, E.; Auburn, S.; Koch, O.; Sanders, M.; Hubbart, C.; Maslen, G.; Ruano-Rubio, V.; Jyothi, D.; Miles, A.; O’Brien, J.; Gamble, C.; Oyola, S. O.; Rayner, J. C.; Newbold, C. I.; Berriman, M.; Spencer, C. C.; McVean, G.; Day, N. P.; White, N. J.; Bethell, D.; Dondorp, A. M.; Plowe, C. V.; Fairhurst, R. M.; Kwiatkowski, D. P. Multiple populations of artemisinin-resistant Plasmodium falciparum in Cambodia. Nat. Genet. 2013, 45, 648-655.

(6) Anthony, M. P.; Burrows, J. N.; Duparc, S.; Moehrle, J. J.; Wells, T. N. The global pipeline of new medicines for the control and elimination of malaria. Malar. J. 2012, 11, 316.

(7) Phillips, M. A.; Rathod, P. K. Plasmodium dihydroorotate dehydrogenase: a promising target for novel anti-malarial chemotherapy. Infect. Disord.: Drug Targets 2010, 10, 226-239.

(8) Phillips, M. A.; Lotharius, J.; Marsh, K.; White, J.; Dayan, A.; White, K. L.; Njoroge, J. W.; El Mazouni, F.; Lao, Y.; Kokkonda, S.; Tomchick, D. R.; Deng, X.; Laird, T.; Bhatia, S. N.; March, S.; Ng, C. L.; Fidock, D. A.; Wittlin, S.; Lafuente-Monasterio, M.; Benito, F. J.; Alonso, L. M.; Martinez, M. S.; Jimenez-Diaz, M. B.; Bazaga, S. F.; Angulo-Barturen, I.; Haselden, J. N.; Louttit, J.; Cui, Y.; Sridhar, A.; Zeeman, A. M.; Kocken, C.; Sauerwein, R.; Dechering, K.; Avery, V. M.; Duffy, S.; Delves, M.; Sinden, R.; Ruecker, A.; Wickham, K. S.; Rochford, R.; Gahagen, J.; Iyer, L.; Riccio, E.; Mirsalis, J.; Bathhurst, I.; Rueckle, T.; Ding, X.; Campo, B.; Leroy, D.; Rogers, M. J.; Rathod, P. K.; Burrows, J. N.; Charman, S. A. A long-duration dihydroorotate dehydrogenase inhibitor (DSM265) for prevention and treatment of malaria. Sci. Transl. Med. 2015, 7, 296 ral11.

(9) Coteron, J. M.; Marco, M.; Esquivias, J.; Deng, X.; White, K. L.; White, J.; Koltun, M.; El Mazouni, F.; Kokkonda, S.; Katneni, K.; Bhamidipati, R.; Shackleford, D. M.; Angulo-Barturen, I.; Ferrer, S. B.; Jimenez-Diaz, M. B.; Gamo, F. J.; Goldsmith, E. J.; Charman, W. N.; Bathurst, I.; Floyd, D.; Matthews, D.; Burrows, J. N.; Rathod, P. K.; Charman, S. A.; Phillips, M. A. Structure-guided lead optimization of triazolopyrimidine-ring substituents identifies potent Plasmodium falciparum dihydroorotate dehydrogenase inhibitors with clinical candidate potential. J. Med. Chem. 2011, 54, 5540-5561.

(10) Gujjar, R.; El Mazouni, F.; White, K. L.; White, J.; Creason, S.; Shackleford, D. M.; Deng, X.; Charman, W. N.; Bathurst, I.; Burrows, J.; Floyd, D. M.; Matthews, D.; Buckner, F. S.; Charman, S. A.; Phillips, 
M. A.; Rathod, P. K. Lead-optimization of aryl and aralkyl amine based triazolopyrimidine inhibitors of Plasmodium falciparum dihydroorotate dehydrogenase with anti-malarial activity in mice. J. Med. Chem. 2011, 54, 3935-3949.

(11) Phillips, M. A.; Gujjar, R.; Malmquist, N. A.; White, J.; El Mazouni, F.; Baldwin, J.; Rathod, P. K. Triazolopyrimidine-based dihydroorotate dehydrogenase inhibitors with potent and selective activity against the malaria parasite, Plasmodium falciparum. J. Med. Chem. 2008, 51, 3649-3653.

(12) Deng, X.; Kokkonda, S.; El Mazouni, F.; White, J.; Burrows, J. N.; Kaminsky, W.; Charman, S. A.; Matthews, D.; Rathod, P. K.; Phillips, M. A. Fluorine modulates species selectivity in the triazolopyrimidine class of Plasmodium falciparum dihydroorotate dehydrogenase inhibitors. J. Med. Chem. 2014, 57, 5381-5394.

(13) Kokkonda, S.; Deng, X.; White, K. L.; Coteron, J. M.; Marco, M.; de Las Heras, L.; White, J.; El Mazouni, F.; Tomchick, D. R.; Manjalanagara, K.; Rudra, K. R.; Chen, G.; Morizzi, J.; Kaminsky, W.; Leroy, D.; Martinez-Martinez, M. S.; Jimenez-Diaz, M. B.; Bazaga, S. F.; Angulo-Barturen, I.; Waterson, D.; Burrows, J. N.; Matthews, D.; Charman, S. A.; Phillips, M. A.; Rathod, P. K. Tetrahydro-2-naphthyl and 2-indanyl triazolopyrimidines targeting Plasmodium falciparum dihydroorotate dehydrogenase display potent and selective antimalarial activity. J. Med. Chem. 2016, 59, 5416-5431.

(14) Phillips, M. A.; White, K. L.; Kokkonda, S.; Deng, X.; White, J.; El Mazouni, F.; Marsh, K.; Tomchick, D. R.; Manjalanagara, K.; Rudra, K. R.; Wirjanata, G.; Noviyanti, R.; Price, R. N.; Marfurt, J.; Shackleford, D. M.; Chiu, F. C; Campbell, M.; Jimenez-Diaz, M. B.; Bazaga, S. F.; Angulo-Barturen, I.; Martinez, M. S.; LafuenteMonasterio, M.; Kaminsky, W.; Silue, K.; Zeeman, A.-M.; Kocken, C.; Leroy, D.; Blasco, B.; Rossignol, E.; Rueckle, T.; Matthews, D.; Burrows, J. N.; Waterson, D.; Palmer, M. J.; Rathod, P. K.; Charman, S. A. A triazolopyrimidine-based dihydroorotate dehydrogenase inhibitor (DSM421) with improved drug-like properties for treatment and prevention of malaria. ACS Infect. Dis. 2016, 2, 945-957.

(15) Deng, X.; Gujjar, R.; El Mazouni, F.; Kaminsky, W.; Malmquist, N. A.; Goldsmith, E. J.; Rathod, P. K.; Phillips, M. A. Structural plasticity of malaria dihydroorotate dehydrogenase allows selective binding of diverse chemical scaffolds. J. Biol. Chem. 2009, 284, 2699927009.

(16) Booker, M. L.; Bastos, C. M.; Kramer, M. L.; Barker, R. H., Jr; Skerlj, R.; Sidhu, A. B.; Deng, X.; Celatka, C.; Cortese, J. F.; GuerreroBravo, J. E.; Crespo-Llado, K. N.; Serrano, A. E.; Angulo-Barturen, I.; Jimenez-Diaz, M. B.; Viera, S.; Garuti, H.; Wittlin, S.; Papastogiannidis, P.; Lin, J. W.; Janse, C. J.; Khan, S. M.; Duraisingh, M.; Coleman, B.; Goldsmith, E. J.; Phillips, M. A.; Munoz, B.; Wirth, D. F.; Klinger, J. D.; Wiegand, R.; Sybertz, E. Novel inhibitors of Plasmodium falciparum dihydroorotate dehydrogenase with anti-malarial activity in the mouse model. J. Biol. Chem. 2010, 285, 33054-33064.

(17) Azeredo, L. F.; Coutinho, J. P.; Jabor, V. A.; Feliciano, P. R.; Nonato, M. C.; Kaiser, C. R.; Menezes, C. M.; Hammes, A. S.; Caffarena, E. R.; Hoelz, L. V.; de Souza, N. B.; Pereira, G. A.; Ceravolo, J. P.; Krettli, A. U.; Boechat, N. Evaluation of 7-arylaminopyrazolo[1,5$\alpha]$ pyrimidines as anti-Plasmodium falciparum, antimalarial, and Pfdihydroorotate dehydrogenase inhibitors. Eur. J. Med. Chem. 2017, $126,72-83$

(18) Kato, N.; Comer, E.; Sakata-Kato, T.; Sharma, A.; Sharma, M.; Maetani, M.; Bastien, J.; Brancucci, N. M.; Bittker, J. A.; Corey, V.; Clarke, D.; Derbyshire, E. R.; Dornan, G. L.; Duffy, S.; Eckley, S.; Itoe, M. A.; Koolen, K. M.; Lewis, T. A.; Lui, P. S.; Lukens, A. K.; Lund, E.; March, S.; Meibalan, E.; Meier, B. C.; McPhail, J. A.; Mitasev, B.; Moss, E. L.; Sayes, M.; VanGessel, Y.; Wawer, M. J.; Yoshinaga, T.; Zeeman, A.-M.; Avery, V. M.; Bhatia, S. N.; Burke, J. E.; Catteruccia, F.; Clardy, J. C.; Clemons, P. A.; Dechering, K. J.; Duvall, J. R.; Foley, M. A.; Gusovsky, F.; Kocken, C. H.; Marti, M.; Morningstar, M. L.; Munoz, B.; Neafsey, D. E.; Sharma, A.; Winzeler, E. A.; Wirth, D. F.; Scherer, C. A.; Schreiber, S. L. Diversity-oriented synthesis yields novel multistage antimalarial inhibitors. Nature 2016, 538, 344-349.

(19) Dancík, V.; Seiler, K. P.; Young, D. W.; Schreiber, S. L.; Clemons, P. A. Distinct biological network properties between the targets of natural products and disease genes. J. Am. Chem. Soc. 2010, 132 , 9259-9261.

(20) Heidebrecht, R. W., Jr.; Mulrooney, C.; Austin, C. P.; Barker, R. H., Jr.; Beaudoin, J. A.; Cheng, K. C.; Comer, E.; Dandapani, S.; Dick, J.; Duvall, J. R.; Ekland, E. H.; Fidock, D. A.; Fitzgerald, M. E.; Foley, M.; Guha, R.; Hinkson, P.; Kramer, M.; Lukens, A. K.; Masi, D.; Marcaurelle, L. A.; Su, X.-Z.; Thomas, C. J.; Weïwer, M.; Wiegand, R. C.; Wirth, D.; Xia, M.; Yuan, J.; Zhao, J.; Palmer, M.; Munoz, B.; Schreiber, S. L. Diversity-oriented synthesis yields a novel lead for the treatment of malaria. ACS Med. Chem. Lett. 2012, 3, 112-117.

(21) Lukens, A. K.; Heidebrecht, R. W., Jr.; Mulrooney, C.; Beaudoin, J. A.; Comer, E.; Duvall, J. R.; Fitzgerald, M. E.; Masi, D.; Galinsky, K.; Scherer, C. A.; Palmer, M.; Munoz, B.; Foley, M.; Schreiber, S. L.; Wiegand, R. C.; Wirth, D. F. Diversity-oriented synthesis probe targets Plasmodium falciparum cytochrome $b$ ubiquinone reduction site and synergizes with oxidation site inhibitors. J. Infect. Dis. 2015, 211, 1097-1103.

(22) Swann, J.; Corey, V.; Scherer, C. A.; Kato, N.; Comer, E.; Maetani, M.; Antonova-Koch, Y.; Reimer, C.; Gagaring, K.; Ibanez, M.; Plouffe, D.; Zeeman, A.-M.; Kocken, C. H.; McNamara, C. W.; Schreiber, S. L.; Campo, B.; Winzeler, E. A.; Meister, S. Highthroughput luciferase-based assay for the discovery of therapeutics that prevent malaria. ACS Infect. Dis. 2016, 2, 281-293.

(23) Lowe, J. T.; Lee, M. D., IV; Akella, L. B.; Davoine, E.; Donckele, E. J.; Durak, L.; Duvall, J. R.; Gerard, B.; Holson, E. B.; Joliton, A.; Kesavan, S.; Lemercier, B. C.; Liu, H.; Marie, J.-C.; Mulrooney, C. A.; Muncipinto, G.; Welzel-O'Shea, M.; Panko, L. M.; Rowley, A.; Suh, B.C.; Thomas, M.; Wagner, F. F.; Wei, J.; Foley, M. A.; Marcaurelle, L. A. Synthesis and profiling of a diverse collection of azetidine-based scaffolds for the development of CNS-focused lead-like libraries. J. Org. Chem. 2012, 77, 7187-7211.

(24) Peukert, S.; Nunez, J.; He, F.; Dai, M.; Yusuff, N.; DiPesa, A.; Miller-Moslin, K.; Karki, R.; Lagu, B.; Harwell, C.; Zhang, Y.; Bauer, D.; Kelleher, J. F.; Egan, W. A method for estimating the risk of druginduced phototoxicity and its application to smoothened inhibitors. MedChem Comm 2011, 2, 973-976. 